\title{
Cosmological Subjectivities: Exploring 'Truth' Environmentalities in the Haa Highlands of Bhutan
}

\author{
Jesse Montes ${ }^{\mathrm{a}, \#}$, Sonam Tshering, ${ }^{\mathrm{a}}$, Tenzin Phuntsho ${ }^{\mathrm{a}}$, and Robert Fletcher ${ }^{\mathrm{b}}$

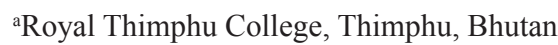

${ }^{\mathrm{b} S}$ Sociology of Development and Change, Wageningen University and Research, Wageningen, The Netherlands

\#Corresponding author E-mail: jessem@rtc.bt

\begin{abstract}
This paper explores local perceptions of the landscape in a small highland community near Haa, Bhutan. Through the lens of ethnoecology, it documents a storied landscape in which an animist cosmology, underpinned by Buddhism, shapes local subjectivities in particular ways that influence behaviour in relation to this landscape. We draw on this case to contribute to a growing body of research exploring how environmental governance understood as Foucauldian-inspired 'environmentality' works to create 'environmental subjects'. While initial work in this area describes a monolithic environmentality, more recent research outlines multiple environmentalities (neoliberal, disciplinary, sovereign and truth) to demonstrate how processes of subject formation occur differently in relation to each of these. Within this research, however, attention to truth environmentality and the particular forms of environmental subjectivity it cultivates has been largely absent thus far. Our analysis addresses this gap by exploring how members of the herding community in the case under investigation describe relationships with a set of cosmological entities that motivate specific self-understandings leading to conservation-conducive behaviour. In this way, our analysis highlights how this particular approach to the 'conduct of conduct' works to shape specific environmental subjectivities beyond those currently highlighted in the burgeoning environmentalities literature.
\end{abstract}

Keywords: Ethnoecology, environmentality, cosmology, subjectivity, Bhutan

\section{INTRODUCTION}

This research employs landscape ethnoecology methodology to explore how 'environmental' subjectivities emerge in relation to cosmological 'storying' of the landscape by members of a Shokuna herding community in rural Bhutan. A burgeoning body of scholarship, building on Agrawal's (2005a,b) seminal research, draws on Foucauldian poststructuralism to describe environmental governance as an 'environmentality' employing disciplinary forms of engagement in conservation projects to

\begin{tabular}{|l|l|}
\hline \multicolumn{2}{|c|}{ Access this article online } \\
\hline Quick Response Code: & Website: \\
\hline & www.conservationandsociety.org \\
\cline { 2 - 2 } & \\
\hline
\end{tabular}

shape particular "“environmental subjects'- people who care about the environment" (2005b: 162). Yet other researchers point out that different forms of environmentality (neoliberal, sovereign or truth) may shape subjects in divergent ways (Fletcher 2010, 2020). While neoliberal and sovereign environmentalities, and the particular forms of subjectivity they pursue, have been explored through a growing range of empirical studies, thus far little attention has been devoted to investigating what Fletcher (2010) calls a truth environmentality: a mode of environmental governance underpinned by systems of belief concerning the fundamental nature and order of the universe. We address this gap herein by exploring how a Buddhist-inspired cosmology within a highland community in western Bhutan shapes specific selfunderstandings leading to conservation-conducive behaviour.

Within this community, local herders describe a cosmological system within which supernatural actors require particular behaviours from human subjects in relation to the landscape, thus promoting a particular 'environmental subject'

Copyright: (C) Montes et al. 2020. This is an open access article distributed under the terms of the Creative Commons Attribution License, which permits unrestricted use and distribution of the article, provided the original work is cited. Published by Wolters Kluwer - Medknow, Mumbai $\mid$ Managed and supported by the Ashoka Trust for Research in Ecology and the Environment (ATREE), Bangalore. For reprints contact: reprints@medknow.com 
aligning with Fletcher's (2010) incipient sketch of a truth environmentality. This worldview requires humans to assume a submissive role in relation to a host of metaphysical entities that demand particular actions in relation to the surrounding landscape in order to demonstrate this fealty. We argue that this case illustrates construction of a particular form of subjectivity informed by a truth environmentality, an art of governing that aims to conduct conduct through claims concerning the nature of reality and humans' role within it (Fletcher 2010). In this way, our study contributes to environmentalities literature by exploring how truth environmentality promotes particular processes of subject formation as well as how the 'environment' is conceptualised within such culturally-specific processes.

In the following, we first position our research within the growing literature on environmentality. We highlight this perspective's potential to investigate alternative forms of subject formation beyond conventional disciplinary modalities that our subsequent case study pursues. We then explain how integration of a focus on Traditional Ecological Knowledge (TEK) can enrich this discussion by problematising the meaning of 'environment' at the heart of the environmentalities discussion, and how investigation grounded in a landscape ethnoecology approach can illuminate this important issue. Following this, we present our case study of landscape cosmology among Shokuna herders in the Haa highlands. We make a case for understanding this cosmology as a truth environmentality that draws on Buddhist belief to encourage a particular form of environmental subjectivity. We conclude by highlighting how the perspective employed in this study contributes to environmentality research as well as potentially to future policymaking by better incorporating local resource users as critical conservation actors.

\section{Environmentality, Novel Modalities and TEK}

'Environmentality' has become a popular concept through which to understand how people perceive and relate to the surrounding environment. Luke (1995) is attributed with originally conceptualising the term, which understands the 'environment' as a battlefield of competing discourses and perceptions regarding human-nonhuman relations. As Luke phrases it, "nature's meanings always will be multiple and unfixed. Only these interpretive acts can construct contestable textual fields... and, once it is rendered intelligible through these discursive processes, it can be used to legitimise almost anything" (1995: 58).

While Luke's focus was on institutions erected via the 1992 Rio Earth Summit that established a new regime of global environmental governance, Agrawal's subsequent work (2005a,b) both built on and departed from Luke's to emphasise the ways that environmentality works as a ground-level process of 'intimate government' to shape 'environmental subjects', highlighting participation and enrollment in state-based programs of conservation management. Agrawal asserts that "regulations, and villagers' practices and words, seem to be part of a process that has reshaped people's understandings" (2005a: 12). Moreover, he contends, "varying levels of involvement in institutional regimes of environmental regulation facilitate new ways of understanding the environment" (2005b: 161). For Agrawal, practice is thus critical to an understanding of subject formation. Actors are enrolled into particular programmes, resulting in a reshaping of values and understandings that allows states to "govern at a distance" as subjects "are willing to work upon themselves to become environmental subjects", or become "people who care about the environment" (2005b: 181, 162).

A substantial body of research has built on Agrawal's framework, in particular, to explore how environmentality operates to influence subjectivity. Yet some have critiqued his perspective as an overly monolithic and top-down approach that both discounts individual agency in subject formation (see Cepek 2011; Jepson et al. 2012; Faye 2016) and ignores the multiple governance rationalities at play in many contexts (Fletcher 2010). Concerning this first point, scholars have criticised how a focus on top-down exercise of governmentality may obscure the ways that subjects employ creative agency to resist or transform efforts to conduct their conduct when participating in environmental programmes. These critics point out that subjects often respond in meaningful ways to express alternative beliefs and values rather than simply conforming to subjectifying pressures (Cepek 2011; Jepson et al. 2012; Singh 2013; Faye 2016; Cortes-Vasquez and Ruiz-Ballesteros 2018).

Regarding multiple governance rationalities, researchers have pointed out that Agrawal's analysis emphasises a specifically disciplinary mode of conduct that fails to take into account other potential environmentalities implied by Foucault's further elaboration of his governmentality concept in The Birth of Biopolitics (2008). Fletcher thus builds on Foucault (2008) to differentiate multiple environmentalities that "while distinct, are not mutually exclusive, but may coexist in any given context" (Fletcher 2010: 177). In his discussion, Fletcher describes sovereign, disciplinary, and truth environmentalities but gives special attention to a neoliberal form. Contra Agrawal, he suggests that particular forms of environmental subjectivity may be cultivated by each modality via different networks of actors that do not necessarily include the state agents central to Agrawal's discussion. This multiple environmentality perspective has been productively employed by a growing body of researchers to explore intricacies of environmental policies and behaviours in a variety of contexts (see e.g. Youdelis 2013; Fletcher 2017; Montes 2020; Fletcher and Cortes-Vazquez 2020).

Thus far, however, this research has primarily focused on disciplinary, neoliberal and/or sovereign environmentalities, leaving the truth modality largely unexplored. This last modality follows from what Foucault called an 'art of government according to truth", which he explained as "the truth of religious texts, of revelation, and of the order of the world" (2008: 311). Yet Foucault spent little time elaborating this concept and subsequent environmentality research has not done so either. In a rare exception, Valladares and Boelens 
(2019) identify competing truth governmentalities in a mining conflict in Ecuador, wherein the state and industry frame 'science' as a truth to promote mining operations that is contested by local residents appealing to their own knowledge and cosmology. Other researchers have also used the truth environmentality concept to illustrate how competing governance rationalities (i.e. disciplinary, sovereign, and neoliberal) come into conversation with and contest local perceptions of and appeals to the nature of reality as justification for environmental action (Erb 2012; Boelens 2014; Bluwstein 2017). While this work provides insight into the politics of environmental governance, there remains a gap in exploring how such environmental truth claims promote particular forms of subject formation distinct from those prescribed by different environmentalities. It is this lacuna that this work seeks to address in developing our first contribution to the environmentalities literature.

\section{Truth Environmentality and TEK}

In developing this intervention, we make a second important contribution to this literature by problematising how the central concept of the 'environment' is commonly understood within this discussion. While this concept remains largely unproblematised in either Agrawal's or subsequent scholars' work, a substantial body of research demonstrates that how people understand their relationship with the non-human world varies widely across contexts in ways that often depart quite dramatically from the common Western depiction of opposing realms of 'nature' and 'culture' in terms of which the environment is conventionally understood as "nature... confined to an ever more passive role" (Escobar 1996: 331; see also e.g. Descola 2014). To address this important issue, we integrate research on 'Traditional Ecological Knowledge' (TEK) that explores the culturally-specific ways that people in different places understand their relationship with the more-than-human world. In summarising this research, Berkes defines TEK as "a cumulative body of knowledge, practice and belief, evolving by adaptive processes and handed down through generations by cultural transmission, about the relationship of living beings (including humans) with one another and with their environment" (2008: 7). In this understanding, TEK is experiential lived knowledge of the landscape (Berkes 2004), that is, a form of practice that is cumulative, dynamic, historical, local, holistic, embedded and moral/spiritual (Menzies and Butler 2006).

The diverse understandings of human-nonhuman relations documented as TEK thus complicates Agrawal's and others' usage of 'the environment', as only one way to understand such relations that is not necessarily reflective of alternative perspectives. To address this issue, we explore how a truth environmentality may embody non-dualistic understandings of such relations that should also be taken into consideration in analyses from this perspective (Fletcher 2010: 177). While Fletcher (2010) suggests that TEK can be understood as a representation of a truth environmentality, no subsequent research has yet followed up this suggestion to explore this potential framing, as we do in the following.

\section{Landscape Ethnoecology}

A common approach to investigating TEK is through ethnoecology. Ethnoecology seeks to understand the interaction between humans and their surroundings, particularly in terms of natural resource use and understandings of human-nonhuman relations. Barrera-Bassols and Toledo define ethnoecology as the "study of how nature is perceived by humans through a screen of beliefs and knowledge, and how humans, through their symbolic meanings and representations, use and/or manage landscapes and natural resources" (2005: 11). Ethnoecological research has been used to explore a wide range of issues including conservation (Iaenn 1999; Henfrey 2002), land classifications (Johnson and Hunn 2010; Da Silva et al. 2016), language/ toponymy (Fowler 2010; Wartmann and Purves 2018), resource use (Toledo et al. 2003; Barrera-Bassols and Toledo 2005; Rokaya et al. 2005; Côrtes et al. 2014), planning (Samuels et al. 2018) and cosmology (Luchman et al. 2009; Johnson 2010). The sub-field of landscape ethnoecology focusses on how the surrounding landscape in particular is perceived and represented by human populations (Johnson and Hunt 2011). Landscapes provide a backdrop in which human interactions are understood materially, socially, and metaphysically.

Johnson's work $(2000,2010)$ is of particular interest as she emphasises storytelling processes that express perceptions of the environment, human-environment relations and issues related to identity and subjectivity. In her work with the Gitksan of Canada, Johnson (2000, 2010) emphasises linkages between the landscape and society, showing how perceptions are a lens "through which to observe and order the world and to understand the place of people on the land" (2000: 304). The idea of relationship is critical to her work in which mutualism is the defining characteristic of Gitksan human-environment interactions. This mutualism manifests in experiences in which "people are part of the land, in an inextricable and even social relationship" (2000: 303). A fascinating element of Johnson's work is that of storying, or what she calls 'trails of story' (2010). The Gitksan people know places and interact with them through generations of resource harvesting, travel and spirituality that have developed a history of societal shared experiences. Teachings from elders introduce an individual to this relationship, which is further developed through "story as well as by actual travel on the land" (2010: 44). These experiences culminate in a 'web of trails' in which the Gitksan interact with the landscape and navigate this intertwined relationship. Johnson (2010) points to this sociality and longstanding interaction as evidence for sustainable relationships between landscapes and indigenous communities that should be encouraged in conservation agendas.

Extending this connection to conservation, Da Silva et al. (2016) explore how indigenous communities target specific resources based on use-values. They note that "local classifications of the landscapes are driven by utilitarian 
motives, such as the accumulate knowledge about natural resources" (2016: 10). The landscape, then, is seen as a record of human interaction in which particular trends and patterns develop according to the practices of a particular sociocultural formation. As such, these patterns are critical for understanding the needs of communities and "future work prioritising natural areas for conservation" (p.10). BarreraBassols and Toldeo also point out that rituals emerge from these patterns of interaction, rituals that:

mimic conservation practices to maintain the (symbolic and material) balance between abundance and scarcity, or weakness and strength. Connectedness means that all actors should work together as a team, otherwise men may not receive the benefits from the borrowed land, and may be punished by nature and the supra-natural beings (2005: 30).

These rituals and resultant behaviours point to the potential for cultivating a particular form of subjectivity consistent with the concept of truth environmentality as outlined earlier.

In what follows we take Da Silva et al. (2016) as a starting point for understanding the herding community's physical interaction with the landscape, but combine this with Johnson's (2010) emphasis on 'storying' in order to understand local perceptions of this landscape and their relation to subject formation. The analysis to follow therefore seeks to integrate discussions of TEK and (truth) environmentality to explore how particular environmental subjectivities are encouraged via the unique relationship herders in Bhutan's Haa Highlands describe within the more-than-human landscape in which they reside.

\section{METHODOLOGY}

The team of researchers consisted of one Canadian, an American and two Bhutanese nationals. One of the Bhutanese was indigenous to the Haa region, providing a critical insider's perspective. Field research was conducted from July 2014-July 2017, involving in depth interviews with four yak herders in the Shokuna region (Figure 1), supplemented by focus group discussions with additional informants. The four herders were members of two different households, of the total of six households resident to the Shokuna area. Input from these informants cannot be generalised to the entire region, of course, but do provide insight into the views of at least some of the region's inhabitants. As the practices and beliefs of the region are limited in terms of documentation, it was deemed critical to generate in-depth data through a case study approach focused on the life histories of a small number of informants, as opposed to generating more superficial data from a larger sample.

During initial fieldwork, our team spent time with the herders to create a landscape vocabulary, an exercise involving freelisting landscape features, which were then associated with flora, fauna, soils, hydrology, use values, and cosmological features (see Meilleur 2010). The team divided the vocabulary

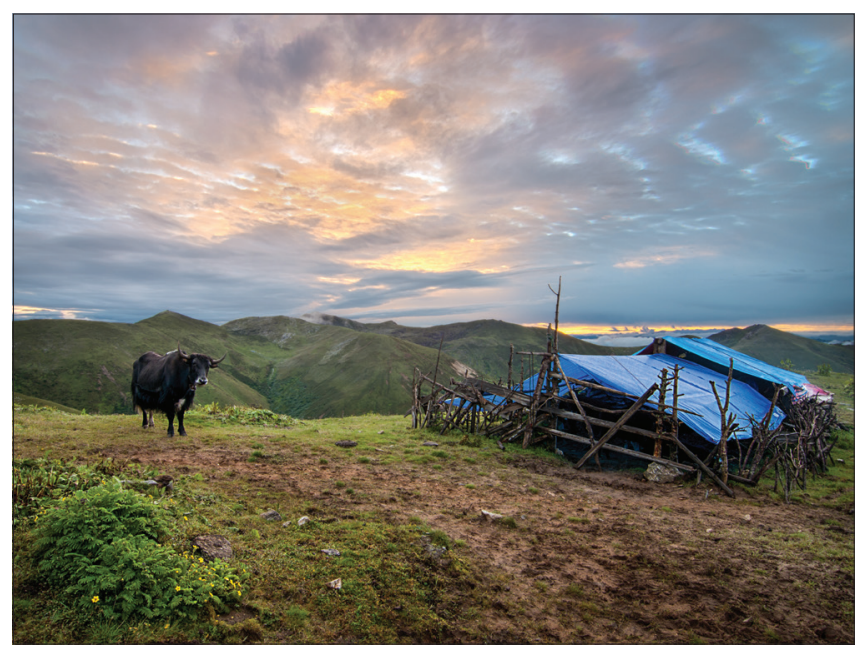

Figure 1

Shokuna Homestead

into four lexical sets in order to better categorise topographic, hydrographic, forest and grassland classifications. The lists were then crosschecked with informants and recharacterised to establish appropriate resonance with local understandings. Informants placed primary emphasis on grassland categories with a number of qualifying distinctions and expansive ethnobotanical knowledge, likely attributed to the primary livelihood in the area, which is solely reliant on pastoralism. With grasslands serving as the primary 'folk biotope', the critical biophysical space for human cultural and production activities, the remaining three categories served as lexical sets to draw further conclusions regarding the broader ethnolandscape, or 'effective environment', of the herding community (Meilleur 2010). Informants revealed a precise knowledge of the landscape through toponymic (place/ feature naming) exercises disclosing features that had both economic and cultural significance. Features with economic importance were expressed through knowledges of material appropriation, both in terms of livelihood sustenance and profit earning potential. Cultural features were often discussed in terms of human-deity interactions. While our intent, as fieldwork continued, was to further provide refined classifications, expand our lexical sets, and to develop insight to use-values, latter trips revealed new critical insight. The researchers particularly noticed within the hydrographic lexical set that proper names assigned to various water bodies had cosmological significance. As we explored the reason for this, stories about the Shokuna area were shared. The concept of 'storying' proved critical; this entailed an animated storytelling process as a means to portray meaning and significance to the local landscape. And it is through this act of storying that an understanding of local subjectivities develops.

\section{RESULTS}

With the northern portion of Bhutan dominated by the southeastern Himalayas, the harsh alpine steppe is home to 
unique flora, fauna, and sociocultural formations. Pasturelands span hills over 4000 metres in elevation welcoming herds and their caretakers. A cycle of seminomadic seasonal movements has occurred for generations developing precise ecosystem knowledge shaped by, and also shaping, an underlying worldview used to interpret the landscape. The number of herders today is less than it was in the past. With advances in education and modernisation, particularly in urban areas, many have abandoned traditional livelihoods. Well educated youth no longer return to the difficult pressures of agriculture and pastoralism, and are drawn to locations such as Thimphu, Paro, and Phuentsholing. The Royal Government is aware of the issue as a large number of unemployed college graduates congregate in urban centres competing for scarce jobs (RGoB 2017). This transition has resulted in an abundance of space, of land left fallow and no longer used. To increase production in these areas the Royal Government implemented the 'Targeted Highland Development Programme' under the eleventh 5-year plan. This programme seeks to increase herd size and production, yet the herder population is not yet targeted for increase and the government aims to maintain an approximate population of 1039 herders in the country (RGoB 2013).

In the highlands of Haa, in the far western region of the country, a pastoral district exists called Shokuna, which is encompassed by the Jigme Khesar Strict Nature Reserve. The area is predominantly used during the monsoon season (June-September), which provides the warmest temperatures in the year allowing herds to access higher altitude grasses. Traditional forms of land allocation persist despite the dramatic decrease of herders and herd size. Prime pastures are redistributed every five years through ritual dice casting (sho), with the champion claiming first choice of the area's resources. This communal decision-making and use of land are indicative of the community relations that the herders in the region share. Modern policies stipulating land rights are not required and would likely disrupt social relations. As Rowbotham comments in regards to land tenure, "people simply cannot be expected to adhere to traditional cultures and values if the link between land, labour and community is drastically or rapidly altered" (2004: 187). To date, the ForestPark staff that monitor the region have largely respected these traditional practices. However, the Land Policy Act of 2007, which was delayed in implementation until 2017, now plans to change such practice (see Tshering et al. 2016) and hence puts at risk these informal institutions.

Shokuna is an area of approximately $66 \mathrm{~km}^{2}$ and is home to approximately 321 yak and 6 households, who mostly identify as Buddhists. While the herders are seminomadic, many have winter homes, or at least some familial connection to the town center of Haa. These connections prove vital for marketing products, mainly cheese, butter and yoghurt, which are distributed to Haa, Paro, and Thimphu. Seasonal movements occur among a number of pasturelands; summer grazing takes place at remote higher altitudes while winter grazing is situated at lower altitudes where fodder can be accessed in forested areas. Local residents hold specific knowledge related to land and resources, translating into situated practices for survival. While nearby Haa town contains a certain remote charm of its own, the highlands of Shokuna lack any sign of human settlement obvious to an outsider. Some might even call it 'wilderness' (Cronon 1996). However, as we spend time with the herders and begin to see their imprint, we come to understand the landscape in a new light. What initially seems an empty untouched space is transformed, in our perception, into a landscape animated with history as locals discuss grazing and fallow patterns, remnants of controlled burns, rock piles signifying previous residences, caves serving as firewood stashes, and so on. During these discussions, which were primarily driven by the four established lexical sets (i.e. topographic, hydrographic, forests and grasslands), spiritual and cosmological significance emerged as a dominant factor in terms of perception and how informants related their own actions to particular landscape features.

\section{Storying the Landscape}

One afternoon, in discussion with two informants, Tshering and Ngawang, we found a spot on a potou, a hilltop used for surveying the area for the presence of yaks, and the two jointly told the story of Rigo Tsho ('Treasure Lake'). Rigo Tsho is a nearby lake that holds immense significance for understanding the topography of the area. Numerous other lakes dotting the landscape originated from the cosmic battle the story tells. With names such as Nga Tsho ('Drum' lake), Ngyaetoe Tsho ('Drumstick' lake), Dung Tsho ('Trumpet' lake), and Rim Tsho ('Cymbal' lake), they all allude to instruments used in Buddhist monastic rituals. As such, the story revealed a landscape cosmology that was absent from our efforts to classify the surroundings in terms of lexical sets. The story was told as follows:

While [Tertön Sherab Mebar] was in Bhutan, he went to the lake called Rigo Tsho...to discover some treasures. He also took some attendants with him so that they could help him in transporting the treasures. When they arrived at the lake, the treasure discoverer instructed his attendants to chop the golden pillar and also told them that they can take the gold chips...which fall while cutting the pillar. Sherab Mebar then sucked the whole lake in his mouth and his disciples went in to chop the pillar and also take out other treasures. The attendants started cutting the pillars in such a way that they could get more golden chips. When the attendants started cutting more, Sherab Mebar yelled at them saying not to cut bigger chunks off the golden pillar and dropped the whole lake out of his mouth. Tertön then quickly grabbed what he could and flew over the mountains. The lake deity then followed him in the form of a storm. The lake was catching up with the Tertön. The Tertön had to drop some of the treasures so that he could run away from the lake. First he dropped a drum and a drumstick. After that he dropped a trumpet. At last he just had a pair of cymbals. Still, the weight was too much for him to flee so he dropped one of the cymbals. After running from the lake 
for some time, Tertön met App Chundu, the famous deity of Haa. App Chundu then helped negotiate between the lake deity and the treasure discoverer. App chundu collected some dried yak and sheep dung and built five laptsas... as a border demarcation between the lake and the Tertön. The Tertön went back with one cymbal. To this day we can see the cymbal in Paro Fortress and it is displayed only once a year to the public. We can also see lakes shaped like the instruments where the Tertön dropped the instruments.

The primary actors in the story, Tertön Sherab Mebar, his attendants, the deity of Rigo Tsho, and App Chundu, all serve important functions. Sherab Mebar is an important historical figure in Bhutan and is known as a Tertön, or 'treasure seeker' foretold by the $8^{\text {th }}$ century Guru Rinpoche. It was Guru Rinpoche who hid treasures throughout the landscape, in preparation for such Tertöns (Hargens 2002). As such, the story makes direct linkage to Buddhist tradition and portrays reverence for the landscape that contains hidden treasures throughout. Sherab Mebar's attendants are characterised negatively in the story. They are understood to be acting in a selfish manner when they oppose the Tertön's instructions.

While this story tells of behaviours to avoid, another story told by Ngawang portrays ideal practice:

If you worship, and believe in the holiness of the lake, they say you'll be blessed. So when [an] elderly monk offered his sincere prayers, the lake offered him blessings for cattle. The lake told him to wish for as many cattle as he could take care of......the elder monk then thought about how he could only take care of about eight or nine cattle.

As Tshering and Ngawang speak about Rigo Tsho and compare the actions of various historical actors, we find that values of moderation and frugality are upheld in contrast to desires for economic gain that negatively impact lake deities and grassland health. As such, a particular set of characteristics and obligations emerge, stemming from interactions with deities. Rigo Tsho, and its understanding as an abode of a deity, produces a basis for understanding subject formation. The Rigo Tsho deity is held in such regard that it puts fear into the famous Tertön Sherab Mebar. Here we see a relational structure forming, similar to the case of Johnson's $(2000,2010)$ Gitksan analyses, in which deities in the landscape interact with and oppose the will of humans. In response, the local yak herders have developed an intricate set of actions and behaviours to avoid the wrath of Rigo Tsho, as well as the numerous other deities in the area. While the number and nature of deities in the area was not explored exhaustively, our team learned that many of the objects in the story of Rigo Tsho that were dropped and formed lakes became the abodes of additional deities. Therefore, the host of deities are appealed to as motivators for particular behaviours and practices within the landscape, shaping the lived experience of herders in the region.

While staying with Ngawang in the summer of 2014, below Nga Tsho and Ngyaetoe Tsho, one of the researchers finished drinking their yak milk tea and poured the remaining milk in the nearby fire. The researcher was quickly scolded and asked not to do this. It was later learned that the smell of burnt milk is offensive and the deities may curse the yak from which the milk came. Such burning of milk is known as othap shoni and was described as follows:

When you burn the milk in the fire, the cow's nipples get wounds... and then its milk content eventually decreases and stops. And if you burn the whole bucket of milk in the fire then ... they have to show it to the blue sky, you have to quickly open up the room and reveal it to the sky, get the milk out of the fire, as much as you can, and then poor it in a clean stream. Otherwise, if that milk turns into a snake, that particular area, the yak cannot go there, it becomes like a haunted area. Yaks can't go in and won't go in. Bad consequences happen like yaks dying, horses dying, even people.

After further discussion, it was found that not only could the milk turn into snakes, but that other animals viewed as harmful could be summoned as well. Ngawang went on to tell of another othap shoni incident that reveals additional insight:

If that milk turns into a tiger, your animals die, will be killed. When you lose your yak, after a while, they will be hunted by a tiger. There's a story of someone who burnt milk in the south of Bhutan, not a long time ago, there is a good herding place there, but now no one goes there anymore..... when they went back the next year during their migration ... they lost around 13-15 yaks. Then they said, 'oh we have to hunt the animal down, it's killing our yaks a lot'. And we were searching in the forest and got chased away by the tiger. They went to an astrologer and the astrologer said that something very inauspicious happened last year. They realised it was [othap shoni], they requested a lama... to do some rituals and solve it. But he got sick when he was there, and he came back and after some time he died. Even now no one goes there. Even yaks are scared to go there.

Additionally, upon our visit in 2015, Tshering and Ngawang were found conducting a ritual as they prepared to move their herd from one area to another. They reported that the local deities needed to be appeased and grant permission before movement of the herds proceeded. Ngawang stated:

[the ritual] is mainly to bless the cattle and the herder, and to avoid bad luck. It is like praying and asking for protection and guidance. Even if a herder arrives and moves to a new camp at dawn, he should perform it. It is mandatory.

In 2016 another herder, Tandin, was also interviewed regarding the spirits in nearby woods. He commented, "I urinate on all the normal trees but I would be scared and would feel very uncomfortable to urinate on a tree where we believe the deities reside". Tandin went on to tell the story of a wrathful deity in the area:

There is a deity where we reside, we can't even cut down trees, not even dead dried trees can be collected. This is 
a very strict deity... when people reach the area they tie their bells on their horse, tie with a cloth so it doesn't make noise. If they are wearing traditional dress, you know how we take off the sleeves ${ }^{1}$ ? They can't even do that, they have to respect [the deity] a lot. They can't even make loud noises. When I was around 15, there was an army man who went hunting there, Ap Gomche,...he shot his gun and then from there his whole body became paralysed. And then he was brought home stiff and paralysed. At home they did some rituals and sent men to do rituals there (the deity's location).

What we find in these tales is a host of deities inhabiting the area, associated with water bodies, trees, and mountaintops. This mosaic of spiritual territories demands specific reciprocities from human dwellers in which prescribed actions and behaviours must be followed in order to continue residing in the area. Some of these actions/behaviours include: avoid burning garbage, refrain from making loud noises, not cutting down certain trees, and conducting specific rituals. BarreraBassols and Toledo (2005) found similar relationships with Mayan settlements in which the landscape was seen as a living being requiring reciprocal actions; where the land was treated in a particular way in order for it to provide food and productive means for residents. In other words, particular beliefs shape specific types of conservation-conducive actions.

The final actor of the Rigo Tsho story, App Chundu, is the local deity of the Haa region who intervenes on behalf of Sherab Mebar, creating a contract and physical barrier that still stands to this day (Figure 2). This physical barrier on the Shokuna landscape serves as a reminder to the local herders of this cosmic interaction and the importance of continued alignment with sanctioned behaviour. The barrier, while initially serving as a contract between Rigo Tsho and Sherab Mebar, has transcended this conflict and now applies to the people of Shokuna, represented by Rigo Tsho, and the people of Pangmisa (region of Paro), the final resting place of Sherab Mebar and the stolen cymbal. Ngawang states that "even the

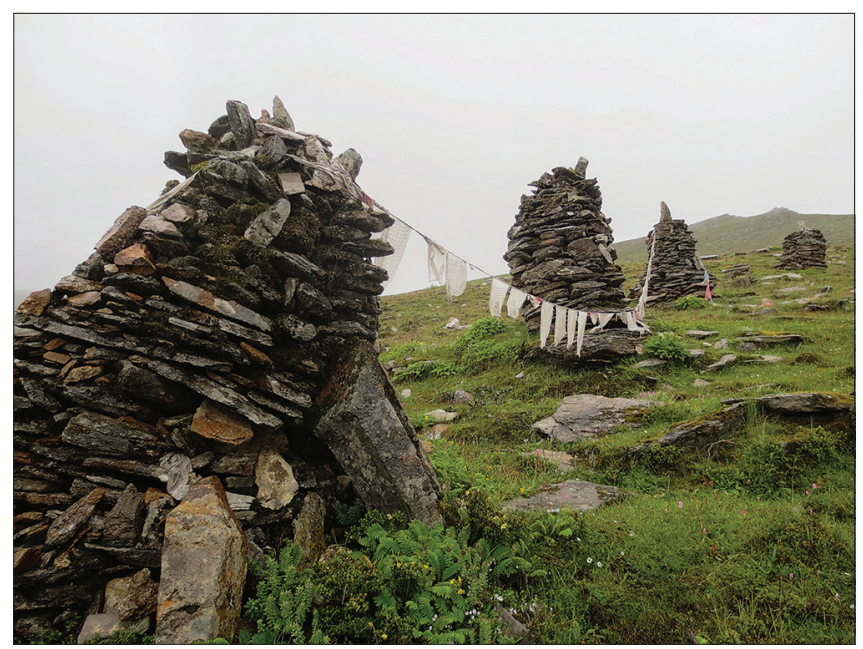

Figure 2

Laptsa structures created by App Chundu
Paro Pangmisa people on the other side were asked not to cross it". With reference to this story, Tshewang (2001) comments: Thus the followers of Terton of Paro Pangmisa do not have any relationship with the people of Ha Shogona [Shokuna]. In later time, a man from Shogona married a girl from Pangmisa. The couple gave birth to a child. The couple thought that there would be no harm in going to Shogona as [the] husband belonged to it. Accordingly, they set out. While crossing a footbridge over the river the knot of the wrapper in which the child was carried suddenly opened on its own in the middle of the wooden-bridge. The child fell into the river and was carried away. It is therefore believed that anyone attempting to break the agreement negotiated by Chungdue [App Chundu] does so at great personal risk (2001: 54-55).

A female interviewee, Pema Eden, from the Paro region reflects on an additional marriage:

The husband is from Pangbisa Paro [Pangmisa], and wife from Sombeykha Haa. They were known to have been in a relationship for a long time, but after they were married, she started having mental breakdowns. Basically, she turned mad. There was one incident where she was home with her kid. The neighbours heard the kid crying and on checking, found the wife just staring at the kid, not responding to the kid's cries. On seeking advice from a lama, they were told it was because they had different 'Choe-suu/Choe-sung' [individual deities]. Later when they finally took the advice of the lama, and divorced, and started living separately, the wife started getting better. In fact, she is doing so well that she is now working as a teacher. The kid stays with the husband, and the wife visits them time to time.

Discussion of App Chundu's laptsa structures then led to referencing other laptsas in the area. Other laptsas were determined to not have relevance to the Rigo Tsho epic, however they retained both practical and spiritual significance. While the herders use laptsas as a way to denote migration routes, as the structures are often found on passes to help reference locations and aid in orienteering, they also serve as waypoints for the spirits of humans who have died and are in transition to Bardo. Describing laptsas and the significance of Bardo, Tandin comments:

[a laptsa] is used as a border demarcation and also helps the traveler not get lost.... No matter how much the herder knows his location, during the thick foggy summer they can get lost for a moment too, so, these help them. These not only help people find their path in this physical world but also help us find a path in the realm of the intermediate. Buddhists believe that when you die you enter into the intermediate realm or Bardo, which is the dimension between the deceased's next life and the life he/she just lived. So, in this intermediate world the deceased have to find a path to the next realm. So, if someone has built laptsas like these on the mountain or contributed a stone 
on it like most of the travelers generally do, it is said that it will help you find a better path. You will see the laptsas as friends in the intermediate realm.

Discussion of App Chundu's role, then, opened up to a wider discussion of physical monuments and waypoints across the landscape. This biophysical grounding provided insight into an integrated worldview in which the physical and spiritual are intertwined and dependent on one another. The role of App Chundu also reinforced the relational interaction between actors and the landscape that included multiple deities. App Chundu is seen to mediate the actions of Rigo Tsho, and has the ability to create agreements between deities and humans. The role of humans, and thus the identity of Shokuna herders, also becomes apparent in these stories. Humans are required to appease the cosmic actors in the landscape, which comes with various prescriptions and restrictions. Asking permission, seeking protection, and avoiding offensive action is required rather than simply operating according to one's own desire.

Another element that emerged from these relations were specific allegiances. Herders reported that certain deities expressed jealousy and demanded loyalty, otherwise repercussions would follow. Tandin explained:

We have to worship different deities. One time my grandfather was about to go down to worship a deity, but first went to another deity in the north. While he was going he went in a truck and the truck got stuck in the mud for the whole day. He then...got a lift and went in a different truck... to that [northern] deity and worshipped and then came back. After coming back he went to the first deity, and the sho didn't show a good sign, it just gave a bad sign.....16 yaks died within two weeks. [And] we couldn't get a single chunk of meat because animals ate all of it. And in my dream I saw I was walking with $z a o^{3}$ and other offerings to that temple, and they wouldn't let me in, they chased me away from the temple. The next day, that is when the 16 yaks started to die within two weeks. Then we went to the astrologer and he said, you have to go to that area, the deity is unsatisfied with your offering.

The story reflects not only jealousy, but also conflicting allegiances that herders must navigate within the landscape through various rituals and behaviours. Therefore, relations with deities drive particular lived experiences, but also, we suggest, subject forming processes characteristic of a truth environmentality.

While our initial research worked towards classifications of the landscape in order to understand perception and identity, it was the process of storying that brought increased critical insight. As Ingold claims "stories, always, and inevitably, draw together what classifications split apart" (2011: 160). The story of Rigo Tsho in particular brought elements together making sense of herder interactions in and perceptions of the landscape.

\section{DISCUSSION}

\section{Characterising a Truth Environmentality}

Cosmologies present particular claims about the nature of the world and create a particular "attunement through practiced skills of perception and action" in which subjects "enter into meaningful relations with the world" (Ingold 2018: 14, 40). As such, these perceptions and relations become part of the myriad lived experiences of actors in the landscape that shape their subjectivity by prescribing particular self-understandings and obligations for practice. Therefore, this case aligns with Agrawal's $(2005 \mathrm{a}, \mathrm{b})$ practice theory to a certain extent by confirming the importance of enrollment in particular forms of practice that encourage particular forms of 'environmental' subjectivity. Rather than participation in state-led projects of the sort that Agrawal emphasises, however, in the Shokuna case such practices result from living within a storied landscape. Cosmology thus structures the "search, practice, and experience through which the subject carries out the necessary transformations on [themselves] in order to have access to the truth" (Foucault 2014: 15).

The everyday engagement of actors with the Shokuna landscape calls for a novel framing that accounts for the relations of power that people experience, and which governs behavior, within this context. The story of Rigo Tsho depicts interaction with a host of local deities. These deities each have a realm of governance that they control, beyond which is space belonging to another deity. There are thus boundaries to these interactions; herders are called into allegiance with localised deities who lay claim over the grasslands, water bodies and other resources that herds depend upon. While boundaries and allegiances are created, particular subjectivities are also created by appeals to this active host of cosmological actors who supervise and assess actions within the landscape. Prescribed behaviours to determine what is and is not permitted have developed over generations as herders learn to properly appease particular deities. As individuals operating in the grasslands, they perceive themselves under the watchful eye of cosmological observers who "supervise the conduct of each individual, to assess it, to judge it, to calculate its qualities and merits" (Foucault 1977: 143). These observations are understood to be pervasive at all times, thus shaping individual behaviours as people make decisions about resource use, migration, and so on. As herders learn to shape their own behaviour, the core appeal is to the existence of a particular cosmology in terms of which certain actions are demanded.

A network of relations is thus narrated and used to understand the relationship between humans and their surroundings. Cosmological actors are understood to be intimately intertwined with production activities and daily life, inflicting harm and blessing and imposing their will upon human actors. This perception of the landscape drives a particular perspective that contrasts with a western scientific model in which humans control, manage, and are perceived as 'above' the environment. Shokuna herders indeed lack the understanding 
that the environment needs 'management'; it is the herders themselves who are 'managed' by cosmological forces. As such, they share in what Johnson describes as relations of mutualism and not of "stewardship, which implies a certain inequality of the participating parties" (2000: 302). Rather than the 'environment' being perceived as a passive space for actors to impose their will upon, the other-than-human realm is an integrated element of the overarching cosmology lacking a dualistic separation between humans and environment (Ingold 2006). These cosmological relationships, revealed through storying of the landscape, do not serve as mere cultural anecdotes or historical fables, but are lived experiences that continue to shape the herders of Shokuna in terms of both self-understanding and behaviour.

Two key elements relevant to our conceptual framework are evident in this case. First, there is an appeal to truth through claims about the nature of humanity and its relationship with other actors inhabiting the surrounding landscape. Second, there is an important contrast evident here with respect to conventional dualist perspectives regarding human-nature relations. As discussed earlier in reference to Escobar's (1996) analysis, a particular framing of the 'environment' has dominated conventional conservation discourse. However, within this truth environmentality, as Shokuna herders make new claims concerning the nature of humanity they also evidence a particular understanding of the nature of the 'environment' to which they relate. Therefore, describing 'environmental' subjectivities of this context is somewhat erroneous as it assumes a culturally specific understanding for the 'environment' not present here. This does not mean, however, that there is a lack in behaviours consistent with what Western science would consider 'environmental' conservation. On the contrary, numerous practices and behaviours could be framed in such a manner, yet they are derived from beliefs and values foreign to conventional science-based practice. Nevertheless, while current conservation programmes in Bhutan have largely adopted strategies from international institutions (Montes 2020), they also adopt discursive framings of the 'environment' which may marginalize local understandings and practice. Therefore, it is critical to account for these ethnoecological findings related to lived experience, in order to account for nuanced framings of 'environment' and human relations with it.

\section{CONCLUSION}

In the Shokuna landscape, material production activities are understood as enmeshed within an integrated cosmological and biophysical realm, contradicting dualist perspectives that dominate technocratic approaches to conservation. Through the process of storying, and specifically the story of Rigo Tsho, local herders describe an animate landscape encompassing myriad metaphysical realities. This worldview is translated into daily rituals, social restrictions, and organisation of the landscape, all of which points to the cultivation of specific forms of environmental subjectivity. We term these 'cosmological subjectivities' as they stem from the set of relationships local herders describe with a host of deities who require and motivate particular behavioral responses within an animated landscape. Herders understand these entities and relationships as elements of reality, inspiring our framing of this cosmology as a specifically truth environmentality.

In addition to contributing a novel element to research on conservation and environmental governance, these findings have important implications for natural resource management decisions going forward. As Bhutan deepens its commitment to conservation policy through projects such as 'Bhutan for Life' (see RGoB and WWF 2019) and promises to achieve 'carbon negativity' (see Tobgay 2016), fulfilling these promises will require an understanding of local subjectivities that have already proven themselves capable of promoting conservationconducive behavior in particular contexts. Building on this recognition, can a truth environmentality be used as a framework for understanding subject formation and promoting conservation initiatives that integrate TEK into overarching environmental management frameworks?

By understanding the landscape as a space of multiple interactions that connect intimately to aspects of culture and self-identity, future policymaking can perhaps better incorporate local residents as critical conservation actors. Pressures on local practices come in many forms including regional plans, development strategies, technological advancements, market forces, and imposed policy measures (Toledo et al. 2003). Rather than opposing local practice and tradition, as seen in conservation practice around the globe (see Vogler et al. 2017; Chirikure et al. 2018), understanding TEK as truth environmentality offers Bhutan and other societies an opportunity to bridge divides between development, environmental management and cultural integrity.

\section{NOTES}

1. Describing an informal wearing of the traditional gho worn by males.

2. Ritual dice used for divination purposes.

3. Traditional snack made of rice.

\section{REFERENCES}

Agrawal, A. 2005a. Environmentality: technologies of government and the making of subjects. Durham and London: Duke University Press.

Agrawal, A. 2005b. Environmentality: community, intimate government, and the making of environmental subjects in Kumaon, India. Current Anthropology 46(2): 161-190.

Barrera-Bassols, N. and V.M. Toledo. 2005. Ethnoecology of the Yucatec Maya: symbolism, knowledge and management of natural resources. Journal of Latin America Geography 4(1): 9-41.

Berkes, F. 2008. Sacred ecology: traditional ecological knowledge and resource management. Philadelphia: Taylor \& Francis.

Berkes, F. 2004. Rethinking community-based conservation. Conservation Biology 18(3): 621-630.

Bluwstein, J. 2017. Creating ecotourism territories: environmentalities in Tanzania's community-based conservation. Geoforum 83: 101-118. 
Boelens, R. 2014. Cultural politics and the hydrosocial cycle: water, power and identity in the Andean highlands. Geoforum 57: 234-247.

Cepek, M.L. 2011. Foucault in the forest: questioning environmentality in Amazonia. American Ethnologist 38(3): 501-515.

Chirikure, S., W. Ndoro, and J. Deacon. 2018. Approaches and trends in African heritage management and conservation. In: Managing heritage in Africa: who cares? (eds. Ndoro, W., S. Chirikure, and J. Deacon). Pp. 1-21. New York: Routledge Press.

Côrtes, L.H.D.O., C.A. Zappes, and A.P.M. Di Beneditto. 2014. Ethnoecology, gathering techniques and traditional management of the crab Ucides cordatus Linnaeus, 1763 in a mangrove forest in south-eastern Brazil. Ocean \& Coastal Management 93: 129-138.

Cortes-Vasquez, J.A. and E. Ruiz-Ballesteros. 2018. Practising nature: a phenomenological rethinking of environmentality in Natural Protected Areas in Ecuador and Spain. Conservation and Society 16(3): 232-242.

Cronon, W. 1996. The trouble with wilderness. In: Uncommon ground (ed. Cronon, W.). Pp. 69-90. New York: W.W. Norton.

Da Silva, T.C., M.F.T. Medeiros, N. Peroni, and U.P. Albuquerque. 2016. Folk classification as evidence of transformed landscapes and adaptive strategies: a case study in the semiarid region of northeastern Brazil. Landscape Research 42(5): 521-532.

Descola, P. 2014. Modes of being and forms of predication. Journal of Ethnographic Theory 4(1): 271-280.

Erb, M. 2012. The dissonance of conservation: environmentalities and the environmentalisms of the poor in eastern Indonesia. Raffles Bulletin of Zoology 25: 3-15.

Escobar, A. 1996. Elements for a post-structuralist political ecology. Futures 28(4): 325-343.

Faye, P. 2016. Adding scepticism about 'environmentality': gender exclusion through a natural resources collectivization initiative in Dionewar, Senegal. In: Dryland forests (eds. Bose, P. and H.V. Dijk). Pp. 95-114. New York: Springer International Publishing.

Fletcher, R. 2010. Neoliberal environmentality: towards a poststructuralist political ecology of the conservation debate. Conservation and Society 8(3): 171-181.

Fletcher, R. 2017. Environmentality unbound: multiple governmentalities in environmental politics. Geoforum 85: 311-315.

Fletcher, R. 2020. Diverse ecologies: mapping complexity in environmental governance. Environment and Planning E: Nature and Space 3(2): 481-502.

Fletcher, R. and J. Cortes-Vazquez. 2020. Beyond the green panopticon: new directions in research exploring environmental governmentality. Environment and Planning E: Nature and Space 3(2): 289-299.

Foucault, M. 1977. Discipline and punish: the birth of the prison. New York: Vintage Books.

Foucault, M. 2008. Birth of biopolitics. New York: Palgrave MacMillan.

Foucault, M. 2014. On the government of the living: lectures at the Collège de France 1979-1980. New York: Palgrave Macmillan.

Fowler, C.S. 2010. What's in a name? Southern Paiute place names as keys to landscape perception. In: Landscape ethnoecology: concepts of biotic and physical space (eds. Johnson, L.M. and E.S. Hunn). Pp. 241-254. New York: Berghahn Books.

Hargens, S.B.F. 2002. Integral development: taking 'The Middle Path' towards Gross National Happiness. Journal of Bhutan Studies 6: 24-87.

Henfrey, T.B. 2002. Ethnoecology, resource Use, conservation and development in a Wapishana Community in the South Rupununi, Guyana. Ph.D thesis. University of Kent, Canterbury, United Kingdom.

Iaenn, N. 1999. The power of environmental knowledge: ethnoecology and environmental conflicts in Mexican conservation. Human Ecology 27(3): 477-491.

Ingold, T. 2006. Rethinking the animate, re-animating thought. Ethnos 71(1): 9-20.
Ingold, T. 2011. Being alive: essays on movement, knowledge, and description. London: Routledge.

Ingold, T. 2018. Back to the future with the theory of affordances. Journal of Ethnographic Theory 8(1/2): 39-44.

Jepson, W., C. Brannstrom, and N. Persons. 2012. "We don't take the pledge": environmentality and environmental scepticism at the epicentre of US wind energy development. Geoforum 43: 851-863.

Johnson, L.M. 2000. “A place that's good," Gitksan landscape perception and ethnoecology. Human Ecology 28(2): 301-325.

Johnson, L.M. 2010. Trail of story, traveller 's path: reflections on ethnoecology and landscape. Edmonton, Canada: Athabasca University Press.

Johnson, L.M. and E.S. Hunn (eds.). 2010. Landscape ethnoecology: concepts of biotic and physical science. New York: Berghahn Books.

Johnson, L.M. and I.D. Hunt. 2011. Ethnoecology and landscapes. In: Ethnobiology (eds. Anderson, E.N., D.M. Pearsall, E.S. Hunn, and N.J. Turner). Pp. 267-284. New Jersey: Wiley-Blackwell.

Luchman, H., J.E. Kim, and S.K. Hong. 2009. Cultural landscape and ecotourism in Bali Island, Indonesia. Journal of Ecology and Field Biology 32(1): 1-8.

Luke, T.W. 1995. On environmentality: geo-power and eco-knowledge in the discourse of contemporary environmentalism. Cultural Critique 31: $57-81$.

Meilleur, B.A. 2010. The structure and role of folk ecological knowledge in Les Allues, Savoie (France). In: Landscape ethnoecology: concepts of biotic and physical space (eds. Johnson, L.M. and E.S. Hunn). Pp. 159-174. New York: Berghahn Books.

Menzies, C.R. and C. Butler. 2006. Introduction: understanding ecological knowledge. In: Traditional ecological knowledge and natural resource management (ed. Menzies, C.R.). Pp. 1-17. Lincoln: University of Nebraska Press.

Montes, J. 2020. Neoliberal environmentality in the land of Gross National Happiness. Environment and Planning E: Nature and Space 3(2): 300-322.

Rowbotham, M. 2004. Cherry Picking in Bhutan. In: Proceedings of the first international conference on Operationalization of Gross National Happiness. Pp. 174-199. Thimphu: Centre for Bhutan Studies.

RGoB (Royal Government of Bhutan). 2013. Eleventh Five Year Plan. Thimphu, Bhutan.

RGoB (Royal Government of Bhutan). 2017. Guideline for the preparation of the $12^{\text {th }}$ Five Year Plan. https://www.gnhc.gov.bt/en/wp-content/ uploads/2017/05/gnh.pdf . Accessed on February 21, 2019.

RGoB (Royal Government of Bhutan) and WWF (World Wildlife Fund). 2019. Bhutan for Life Prospectus. http://www.bfl.org.bt/resources/ BFL_Prospectus.pdf. Accessed on February 19, 2019.

Rokaya, M.B., M.R. Shrestha, and S.K. Ghimire. 2005. Ethnoecology of natural environment in trans-himalayan region of west Nepal. Banko Janakari 15(2): 13-18.

Samuels, M.I., M. Swarts, A. Schroder, K. Ntombela, and C. Cupido. 2018 Through the lens of a herder: insights into landscape ethno-ecological knowledge on rangelands in Namaqualand. Anthropology Southern Africa 41(2): 136-152.

Singh, N.M. 2013. The affective labor of growing forests and the becoming of environmental subjects: rethinking environmentality in Odisha, India. Geoforum 47: 189-198.

Tobgay, T. 2016. This country isn't just carbon neutral - its carbon negative. https://www.ted.com/talks/tshering_tobgay_this_country_isn_t just_ carbon_neutral_it_s_carbon_negative. Accessed on February 19, 2019.

Toledo, V.M., B. Ortiz-Espejel, L. Cortes, P. Moguel, and M. Ordonez. 2003. The multiple use of tropical forests by indigenous peoples in Mexico: a case of adaptive management. Conservation Biology 7(3): 1-17.

Tshewang, P. 2001. History of Has(Ha) Valley. Journal of Bhutan Studies 5: 50-56.

Tshering, K., W. Ning, K. Phuntsho, N. Chhetri, N. Bidha, and K. Dema. 2016. 
Autumn. the fate of traditional rangeland management practices under Bhutan's changing policies and socio-economic conditions. Bhutan Journal of Research \& Development: 53-66.

Valladares, C. and R. Boelens. 2019. Mining for mother earth: governmentalities, sacred waters and nature's rights in Ecuador. Geoforum 100: 68-79.

Vogler, D., S. Macey, and A. Sigouin. 2017. Stakeholder analysis in environmental and conservation planning. Lessons in Conservation 7: 5-16.

Wartmann, F.M. and R.S. Purves. 2018. Investigating sense of place as a cultural ecosystem service in different landscapes through the lens of language. Landscape and Urban Planning 175: 169-183.

Youdelis, M. 2013. The competitive (dis)advantages of ecotourism in Northern Thailand. Geoforum 50: 161-171.

Received: 27-Mar-2019; Revised: 11-Jun-2020; Accepted: 20-Jul-2020; Published: 07-Sep-2020 